0

\title{
Heterogeneous photocatalytic degradation and mineralization of 2,4-dichlorophenoxy acetic acid (2,4-D): its performance, kinetics, and economic analysis
}

\author{
Gamze Dogdu Okcu ${ }^{\mathrm{a}}$, Hatice Eser Okten ${ }^{\mathrm{b}}$, Arda Yalcuk ${ }^{\mathrm{a}, *}$ \\ ${ }^{a}$ Department of Environmental Engineering, Abant Izzet Baysal University, 14030 Golkoy Campus, Bolu, Turkey, \\ emails: ayalcuk@gmail.com (A. Yalcuk),dogdu.gamze@gmail.com (G.D. Okcu) \\ ${ }^{b}$ Department of Environmental Engineering, Izmir Institute of Technology, 35430 Urla, Izmir, Turkey, email: eserokten@gmail.com
}

Received 12 April 2018; Accepted 24 October 2018

\section{A B S T R A C T}

The photocatalytic degradation and mineralization of commercial solution of 2,4-dichlorophenoxyacetic acid (2,4-D) was carried out by UVA/P25 TiO and UVA/P25 TiO $/ \mathrm{H}_{2} \mathrm{O}_{2}$ oxidation processes under batch-mode conditions. In $\mathrm{UVA}+\mathrm{TiO}_{2}$ photocatalysis $\left(\mathrm{TiO}_{2} 1.5 \mathrm{gL}^{-1}, \mathrm{pH}\right.$, initial 2,4-D 25 $\left.\mathrm{mg} \mathrm{L}^{-1}\right), 97.47 \% \pm 0.27 \%$ degradation, $39.89 \% \pm 3.42 \%$ mineralization, and $65.52 \% \pm 4.88 \%$ oxidation were achieved in $180 \mathrm{~min}$, and in $\mathrm{UVA}+\mathrm{TiO}_{2}+\mathrm{H}_{2} \mathrm{O}_{2}$ photocatalysis $\left(\mathrm{TiO}_{2} 1.5 \mathrm{~g} \mathrm{~L}^{-1}, \mathrm{pH}\right.$ 5, initial 2,4-D $\left.25 \mathrm{mg} \mathrm{L}^{-1}, \mathrm{H}_{2} \mathrm{O}_{2} 150 \mathrm{mg} \mathrm{L}^{-1}\right), 99.74 \% \pm 0.08 \%$ degradation, $55.99 \% \pm 2.67 \%$ mineralization, and $82.49 \% \pm 1.90 \%$ oxidation were obtained in $180 \mathrm{~min}$. The pseudo-first-order kinetic model fitted the experimental data well, and the photocatalytic degradation process was explained by the modified $\mathrm{L}-\mathrm{H}$ model; $k_{c}$ and $K_{\mathrm{LH}}$ were $1.293 \mathrm{mg} \mathrm{L}^{-1} \mathrm{~min}^{-1}$ and $0.232 \mathrm{~L} \mathrm{mg}^{-1}$, respectively. Fourier transform infrared (FTIR) spectroscopy spectra and scanning electron microscopy (SEM) analysis indicated degradation of organic bonds of the herbicide and adsorption of 2,4-D particles onto the $\mathrm{TiO}_{2}$ catalyst during 24-h experiments. Moreover, the dependence of $k_{\text {app }}$ on the half-life time was determined by calculating the electrical energy per order $\left(E_{\mathrm{EO}}\right)$. UVA/TiO ${ }_{2} / \mathrm{H}_{2} \mathrm{O}_{2}$ photocatalysis may be applied as a pretreatment to 2,4-D herbicide wastewater at a $\mathrm{pH}$ of 5 for biological treatment.

Keywords: 2,4-dichlorophenoxyacetic acid (2,4-D); Cost analysis; Electrical energy per order; Photocatalytic degradation; Mineralization; $\mathrm{UVA} / \mathrm{TiO}_{2} / \mathrm{H}_{2} \mathrm{O}_{2}$ 